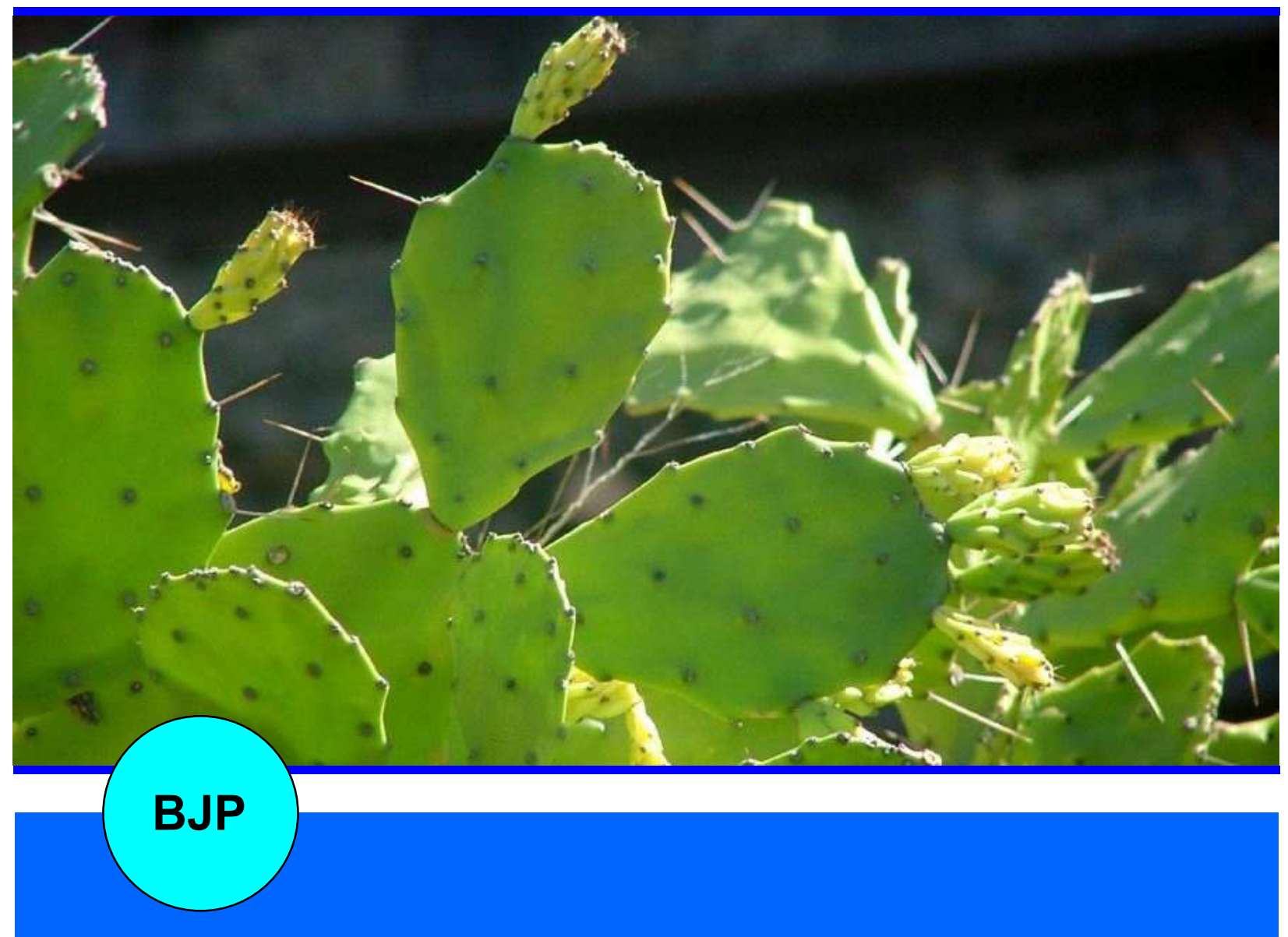

Bangladesh Journal of Pharmacology

Research Article

Evaluation of hepatoprotective effect of chloroform and methanol extracts of Opuntia monacantha in paracetamol-induced hepatotoxicity in rabbits 


\title{
Evaluation of hepatoprotective effect of chloroform and methanol extracts of Opuntia monacantha in paracetamol-induced hepatotoxicity in rabbits
}

\author{
Mohammad Saleem', Iram Irshad', Muhammad Kashif Baig' and Faiza Naseer'1 \\ ${ }^{1}$ College of Pharmacy, GC University, Faisalabad, Pakistan; ${ }^{2}$ Independent Medical College, Faisalabad, Pakistan.
}

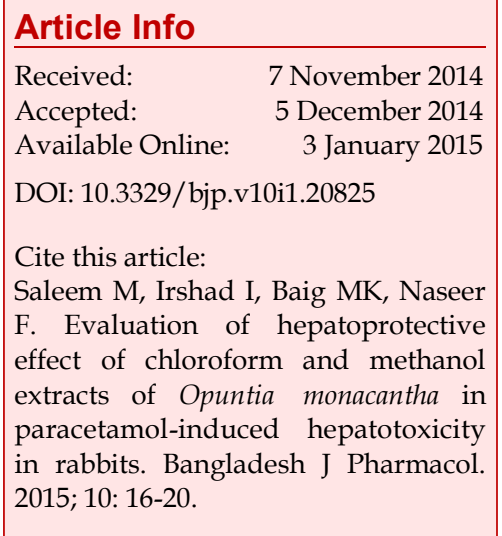

\begin{abstract}
The chloroform and methanol extracts of Opuntia monacantha were studied for its hepatoprotective effect against paracetamol-induced liver damage in rabbits. Results proved that both extracts at 200, 400 and $600 \mathrm{mg} / \mathrm{kg}$ body weight in one week protocol showed significant $(\mathrm{p}<0.001)$ hepatoprotective activity by reducing the magnitude of liver markers including alanine aminotransferase, aspartate aminotransferase, alkaline phasphatase and total bilirubin levels. The results were supported by histopathological studies of liver tissue. Chemical analysis of O. monacantha indicated the presence of alkaloids, tannins, saponins, flavonoids and polysaccharides and its hepatoprotective potential may be due to the presence of flavonoids. Its is concluded that $600 \mathrm{mg} / \mathrm{kg}$ is the potent dose of both extracts of $O$. monacantha as a hepatoprotective plant.
\end{abstract}

\section{Introduction}

The liver is "Great Chemical Factory" of the body as involved in regulation, synthesis, storage and secretion of many important proteins, nutrients and chemicals. The liver is also involved in detoxification of toxic chemicals and xenobiotics. It is exposed to various toxins, changing liver functions and eventually leading to liver ailments like hepatitis, cirrhosis and alcoholic liver disease (Ahsan et al., 2009). During many biochemical processes, free radical reactive oxygen species are generated that cause liver injury (Ali et al., 2004). Antioxidants can scavenge free radicals, thus limiting the process of hepatic cell necrosis (Raja et al., 2006). The investigation of natural plants and isolation of their beneficial constituents is very vital to control liver disease (Saleem and Naseer, 2014). Many hepatoprotective plants have been identified like Cocculus hirsutus (Thakare et al., 2009), Carissa spinarum (Hegde and Joshi, 2010), Khamira Gaozaban Ambri Jadwar Ood Saleeb Wala (Akhtar et al., 2013), Trichodesma sedgwickianum (Saboo et al., 2013), Trianthema decandra
(Balamurugan and Muthusamy, 2008), Convolvulus arvensis (Ali et al., 2013), Ipomoea staphylina (Bag and Mumtaz, 2013), Malva parviflora (Mallhi et al., 2014), Chenopodium murale (Saleem et al., 2014) and Rumex dentatus (Saleem et al., 2014). Though we know the hepatoprotective and antioxidant potential of many plants, but still there is much less information available regarding the hepatoprotective potential of Opuntia monacantha commonly known as Chnutarthar from family: Cactaceae (Ahmad, 2007). This herb has been used for liver impairment traditionally but there is no scientific evidence available. Hence this study was undertaken with the objective to explore the hepatoprotective potential of $O$. monacantha.

O. monacantha has been used in urinary tract tumors, piles, inflammations, anemia, ulcers and enlargement of the spleen (Galati et al., 2002). The flowers have been used for respiratory and ophthalmic complaints and fruit in gonorrhea (Ahmad, 2007). It has a traditional use as a medicinal agent for burns, indigestion and as antipyretic agent (Kifayatullah and Waheed, 2014). 
Polysaccharides separated from $O$. monacantha have anti -diabetic and antiglycated activity. It also possesses free radical scavenging, antioxidant and antimicrobial potential (Bari et al., 2012).

Thus, the objective of the present study was to evaluate the hepatoprotective activity of the chloroform and methanol extracts of $O$. monacantha against paracetamol -induced liver damage in rabbits.

\section{Materials and Methods}

\section{Collection of plants}

The plant was collected from district Faisalabad, Punjab Pakistan. The plant was identified and authenticated by Dr. Mansoor Hameed, Department of Botany, University of Agriculture, Faisalabad. Voucher No. 1027-2012 can be used for future references.

\section{Preparation of plant extract}

The collected plant was cleaned, washed and dried under shade for a week and was pulverized in a mechanical grinder. The powder obtained $(3 \mathrm{~kg})$ was successively macerated first in chloroform (9L) and then in methanol (9L) solvents for seven days in airtight vessels with occasional shaking at room temperature. Then filtration was done with Whatman filter paper No. 1 and the filtrates were concentrated in a rotary evaporator at $61^{\circ} \mathrm{C}$ for chloroform extract and at $65^{\circ} \mathrm{C}$ for methanol extract. The concentrate was stored at $4^{\circ} \mathrm{C}$ in dark amber colored bottle (Ahmad and Eram, 2011).

\section{Experimental animals}

Rabbits were used as experimental animals in the study weighing between 1.2-1.5 kg. Standard diet and water ad libitum were given to them.

\section{Experimental protocol}

Fifty four rabbits were divided into 9 groups. Each group having 6 rabbits. The study was continued for a week (Grish et al., 2009; Yasmin et al., 2010). The study protocol was approved by the Ethical Review Committee, GC University, Faisalabad, Pakistan.

Group I received distilled water ( $5 \mathrm{~mL} / \mathrm{kg}$ p.o) daily for seven days and served as normal control. Group II received distilled water $(5 \mathrm{~mL} / \mathrm{kg}$ p.o) daily and paracetamol $(2,000 \mathrm{mg} / \mathrm{kg})$ after three hours daily for seven days.

Group III received standard drug silymarin $(100 \mathrm{mg} /$ $\mathrm{kg})$ and paracetamol $(2,000 \mathrm{mg} / \mathrm{kg})$ after three hours daily for seven days.

Group IV received a chloroform extract of $O$. monacantha $(200 \mathrm{mg} / \mathrm{kg})$ and paracetamol (2,000 mg/ $\mathrm{kg}$ ) after three hours daily for seven days.

Group V received a chloroform extract of O. monacantha
(400 mg/ $\mathrm{kg})$ and paracetamol $(2,000 \mathrm{mg} / \mathrm{kg})$ after three hours daily for seven days.

Group VI received a chloroform extract of $O$. monacantha $(600 \mathrm{mg} / \mathrm{kg})$ and paracetamol $(2,000 \mathrm{mg} /$ $\mathrm{kg}$ ) after three hours daily for seven days.

Group VII received methanol extract of O. monacantha $(200 \mathrm{mg} / \mathrm{kg})$ and paracetamol $(2,000 \mathrm{mg} / \mathrm{kg})$ after three hours daily for seven days.

Group VIII received a methanol extract of $O$. monacantha $(400 \mathrm{mg} / \mathrm{kg})$ and paracetamol $(2,000 \mathrm{mg} /$ $\mathrm{kg}$ ) after three hours daily for seven days.

Group IX received a methanol extract of $O$. monacantha $(600 \mathrm{mg} / \mathrm{kg})$ and paracetamol $(2,000 \mathrm{mg} / \mathrm{kg})$ after three hours daily for seven days.

\section{Biochemical investigation}

In this study, evaluation of hepatoprotective activity was done biochemically and histopathologically. On the $8^{\text {th }}$ day, blood samples were taken and clotted for 45 min at room temperature and serum was separated by centrifugation at 2,500 rpm for $15 \mathrm{~min}$. Separated serum was used for the estimation of biochemical parameters like alanine aminotransferases (ALT), aspartate aminotransferases (AST), alkaline phosphatases (ALP) and total bilirubin level (Ali et al., 2013).

\section{Histopathological examination}

Histopathological studies were performed in the Pathology Lab of the Independent University, Hospital, Faisalabad, Pakistan to examine the microscopic changes in liver anatomy (Saleem et al., 2014). After 48 hours of the last dose of treatment, phenobarbitone anesthesia (35 mg/kg i.p.) was given and animals were slaughtered. Liver from each animal was removed after dissection and preserved in $10 \%$ formalin. Sections of livers stained with hematoxylin and eosin were observed microscopically for histopathological changes.

\section{Preliminary phytochemical analysis}

Phytochemical analysis was done to determine the presence of alkaloids, tannins, saponins and flavonoids, polysaccharides, steroids and anthraquinones (Bari et al., 2012).

\section{Statistical analysis}

Values were represented as mean \pm SEM and data was analyzed by one-way ANOVA. Values were taken as significant $\mathrm{p}<0.001$.

\section{Results}

Hepatoprotective effect of chloroform and methanolic extracts at 200, 400 and $600 \mathrm{mg} / \mathrm{kg}$ were determined by estimating liver enzymes: AST, ALT, ALP and TB. The average value of the AST of normal animals was $66.8 \pm$ 
Table I

Effect of chloroform and methanolic extracts of O. monacantha on AST, ALT, ALP and TB levels

\begin{tabular}{|lrrrr|}
\hline Treatment & \multicolumn{1}{c}{$\begin{array}{c}\text { TB } \\
(\mathrm{mg} / \mathrm{dL})\end{array}$} & \multicolumn{1}{c|}{$\begin{array}{c}\text { ALT } \\
(\mathrm{U} / \mathrm{L})\end{array}$} & \multicolumn{1}{c|}{$\begin{array}{c}\text { AST } \\
(\mathrm{U} / \mathrm{L})\end{array}$} & \multicolumn{1}{c|}{$\begin{array}{c}\text { ALP } \\
(\mathrm{U} / \mathrm{L})\end{array}$} \\
\hline Distill water & $0.7 \pm 0.0$ & $68.2 \pm 4.7$ & $66.8 \pm 8.4$ & $117.3 \pm 5.3$ \\
Distill water + Paracetamol $(2,000 \mathrm{mg} / \mathrm{kg})$ & $3.3 \pm 0.2$ & $165.3 \pm 22.4$ & $115.6 \pm 12.2$ & $223.3 \pm 7.7$ \\
Silymarin $(100 \mathrm{mg})+$ Paracetamol $(2,000 \mathrm{mg} / \mathrm{kg})$ & $0.5 \pm 0.0$ & $68.8 \pm 7.7$ & $75.5 \pm 8.4$ & $133.5 \pm 9.9$ \\
Chloroform extract $(200 \mathrm{mg})+$ Paracetamol $(2,000 \mathrm{mg} / \mathrm{kg})$ & $1.8 \pm 0.3$ & $98.3 \pm 6.6$ & $86.3 \pm 4.5$ & $145.6 \pm 7.7$ \\
Chloroform extract $(400 \mathrm{mg})+$ Paracetamol $(2,000 \mathrm{mg} / \mathrm{kg})$ & $1.3 \pm 0.2$ & $95.3 \pm 16.0$ & $82.5 \pm 11.9$ & $141.5 \pm 9.5$ \\
Chloroform extract $(600 \mathrm{mg})+$ Paracetamol $(2000 \mathrm{mg} / \mathrm{kg})$ & $1.0 \pm 0.1$ & $93.6 \pm 6.6$ & $80.8 \pm 6.4$ & $138.5 \pm 6.2$ \\
Methanol extract $(200 \mathrm{mg})+$ Paracetamol $(2000 \mathrm{mg} / \mathrm{kg})$ & $1.6 \pm 0.2$ & $99.0 \pm 5.9$ & $98.2 \pm 6.7$ & $145.0 \pm 2.1$ \\
Methanol extract $(400 \mathrm{mg})+$ Paracetamol $(2,000 \mathrm{mg} / \mathrm{kg})$ & $1.2 \pm 0.3$ & $80.1 \pm 8.0$ & $90.0 \pm 5.8$ & $141.7 \pm 17.6$ \\
Methanol extract $(600 \mathrm{mg})+$ Paracetamol $(2,000 \mathrm{mg} / \mathrm{kg})$ & $1.1 \pm 0.1$ & $76.1 \pm 4.7$ & $78.2 \pm 7.2$ & $139.5 \pm 11.8$ \\
\hline
\end{tabular}

8.4 U/L. Treatment with paracetamol raised this value to $115.6 \pm 12.2 \mathrm{U} / \mathrm{L}$. Administration of chloroform extract of O. monacantha at a dose of 200, 400 and 600 $\mathrm{mg} / \mathrm{kg}$ brought this enzyme level to $86.3 \pm 4.5 \mathrm{U} / \mathrm{L}$, $82.5 \pm 11.9 \mathrm{U} / \mathrm{L}$ and $80.8 \pm 6.4 \mathrm{U} / \mathrm{L}$ respectively, but the methanol extract with same doses altered the AST level as $98.2 \pm 6.7 \mathrm{U} / \mathrm{L}, 90.0 \pm 5.8 \mathrm{U} / \mathrm{L}$ and $78.2 \pm 7.2 \mathrm{U} / \mathrm{L}$ respectively which was comparable to standard hepatoprotective drug silymarin AST level 75.5 $\pm 8.4 \mathrm{U} /$ $\mathrm{L}(\mathrm{p}<0.001)$ (Table I).

The average value of ALT of normal animals was $68.2 \pm$ $4.7 \mathrm{U} / \mathrm{L}$. Treatment with paracetamol raised this value up to $165.3 \pm 22.4 \mathrm{U} / \mathrm{L}$. Administration of chloroform extract of O. monacantha at a dose of 200, 400 and 600 $\mathrm{mg} / \mathrm{kg}$ brought this enzyme level to $98.3 \pm 6.6 \mathrm{U} / \mathrm{L}$, $95.3 \pm 16.0 \mathrm{U} / \mathrm{L}$ and $93.6 \pm 6.6 \mathrm{U} / \mathrm{L}$ respectively and methanol extract decreased to $99.0 \pm 5.9 \mathrm{U} / \mathrm{L}, 80.1 \pm 8.0$ $\mathrm{U} / \mathrm{L}$ and $76.1 \pm 4.7 \mathrm{U} / \mathrm{L}$ respectively which was comparable to silymarin $68.8 \pm 7.7 \mathrm{U} / \mathrm{L}(\mathrm{p}<0.001)$ (Table I).

\section{Table II}

Phytochemical analysis of Opuntia monacantha

\begin{tabular}{|lcc|}
\hline Compounds & Chloroform extract & Methanol extract \\
\hline Alkaloids & + & + \\
Polysaccharides & + & + \\
Tannins & + & + \\
Saponins & + & + \\
Flavonoids & + & + \\
Steroids & - & - \\
Anthraquinones & - & - \\
\hline
\end{tabular}

The average value of ALP of normal animals was 117.3 $\pm 5.3 \mathrm{U} / \mathrm{L}$. Treatment with paracetamol raised this value to $223.3 \pm 7.7 \mathrm{U} / \mathrm{L}$. Administration of chloroform extract of O. monacantha at a dose of 200, 400 and 600 $\mathrm{mg} / \mathrm{kg}$ brought this enzyme level to $145.6 \pm 7.7 \mathrm{U} / \mathrm{L}$, $141.5 \pm 9.5 \mathrm{U} / \mathrm{L}$ and $138.5 \pm 6.2 \mathrm{U} / \mathrm{L}$ respectively, and methanol extract with same doses decreased enzyme to $145.0 \pm 2.1 \mathrm{U} / \mathrm{L}, 141.7 \pm 17.6 \mathrm{U} / \mathrm{L}$ and $139.5 \pm 11.8 \mathrm{U} / \mathrm{L}$ respectively, compared to silymarin $133.5 \pm 9.9 \mathrm{U} / \mathrm{L}$ $(\mathrm{p}<0.001)$ (Table I)

The average value of TB of normal animals was $0.7 \pm 0.0$ $\mathrm{mg} / \mathrm{dL}$. Treatment with paracetamol raised this value to $3.3 \pm 0.2 \mathrm{mg} / \mathrm{dL}$. Administration of chloroform extract of O. monacantha at a dose of 200, 400 and 600 $\mathrm{mg} / \mathrm{kg}$ brought this level to $1.8 \pm 0.3 \mathrm{mg} / \mathrm{dL}, 1.3 \pm 0.2$ $\mathrm{mg} / \mathrm{dL}$ and $1.0 \pm 0.1 \mathrm{mg} / \mathrm{dL}$ respectively, and methanol extract to $1.6 \pm 0.2 \mathrm{mg} / \mathrm{dl}, 1.2 \pm 0.3 \mathrm{mg} / \mathrm{dL}$ and $1.1 \pm 0.1$ $\mathrm{mg} / \mathrm{dL}$ respectively, compared to silymarin $0.5 \pm 0.0$ $\mathrm{mg} / \mathrm{dL}(\mathrm{p}<0.001)$ (Table I).

Histopathological studies showed that the liver tissues were normal in the control group. Paracetamol treated group showed inflammation and tissue necrosis. Silymarin treated group showed mild inflammation. Animals treated with chloroform extract of $O$. monacantha showed mild inflammation that was comparable to standard drug. Maximum protection was shown in the dose of $600 \mathrm{mg} / \mathrm{kg}$. Animals treated with methanolic extract of $O$. monacantha also showed a hepatoprotective effect and it was more pronounced with $600 \mathrm{mg} / \mathrm{kg}$ extract dose shown in Figure 1.

The Phytochemical Screening showed the presence of alkaloids, tannins, saponins, Polysaccharides and flavonoids and absence of steroids and anthraquinones in both chloroform and methanolic extracts (Table II). 


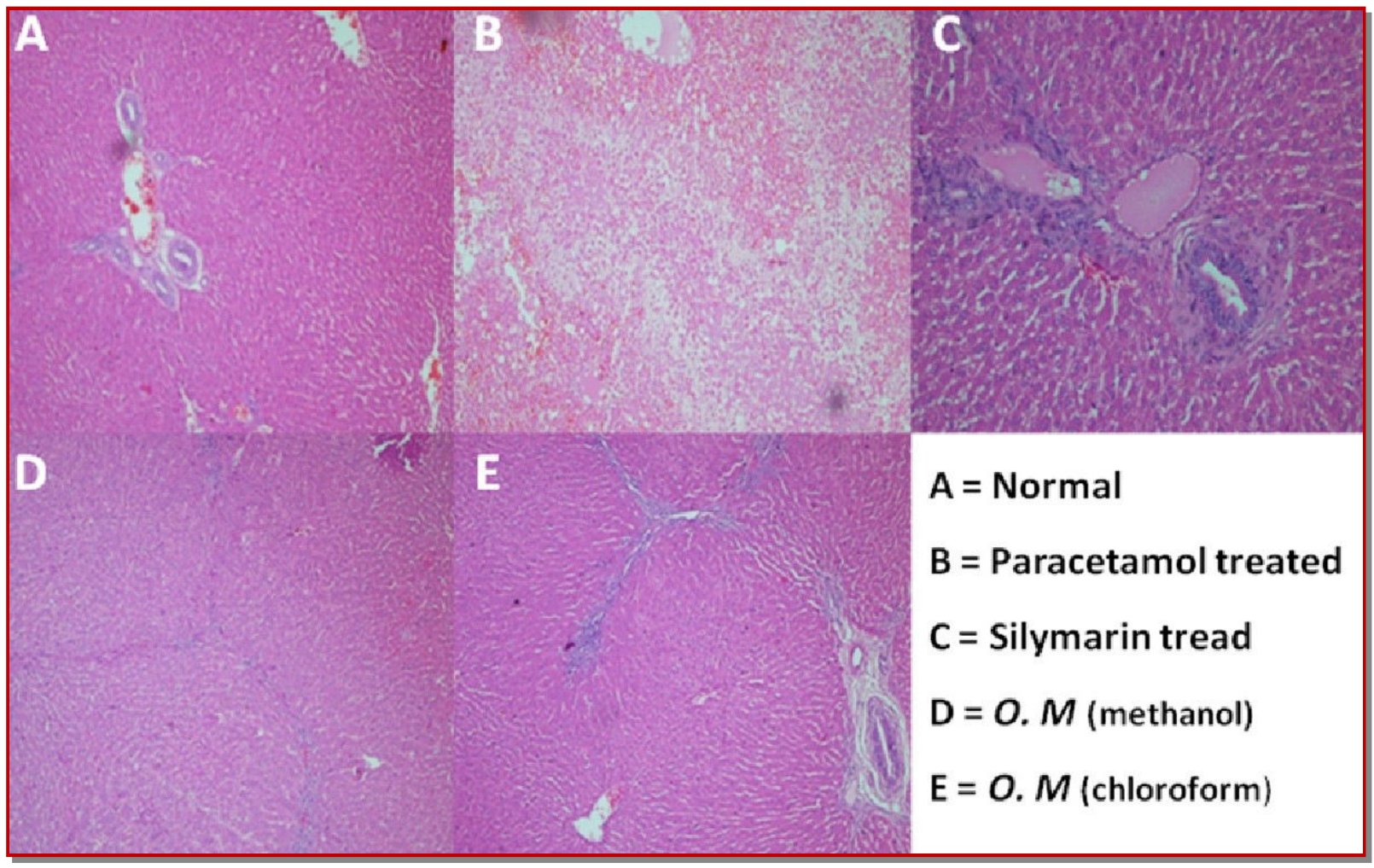

Figure 1: Histopathological study of liver sections of rabbit; (A) Normal group: Liver section showing normal liver morphology; hepatocytes has a round nucleus centrally homogenous cytoplasm, flat endothelial cells around central vein and sinusoid. (B) Paracetamol treated group: showing liver architecture is destroyed, showing replacement of hepatocytes by inflammatory cells comprising neutrophils and rare lymphocytes. The hepatocytes showed necrosis with intervening hemorrhage. (C) Silymarin treated group: In liver section, 1-2 hepatocytes rows around the central vein showed; hepatic cell degeneration along with necrosis (loss of nuclei), less injury of endothelial cells around central vein and less fat vacuoles in hepatocytes (D) O. monacantha (Methanol) treated group: liver architecture was maintained showing normal arrays of hepatocytes with intervening normal sinusoids. The hepatocytes were normal polygonal with granular eosinophilic cytoplasm and round nuclei. The portal tracts were normal with few lymphocytes. (E) O. monacantha (Chloroform) treated group: In liver section, 1-2 hepatocytes rows around the central vein showed; hepatic cell degeneration along with necrosis (loss of nuclei), less injury of endothelial cells around central vein and less fat vacuoles in hepatocytes

\section{Discussion}

Paracetamol-induced liver toxicity and cell death are due to generation of toxic metabolites after its metabolism through CYP-450 (Ibrahim et al., 2011). It is converted into $\mathrm{N}$-acetyl P-benzoquinineimine, produces oxidative stress and causes glycogen and glutathione depletion by irreversible conjugation with sulfhydral groups of glutathione (Saleem and Naseer, 2014). In the present study protective effect of chloroform and methanol extract of $O$. monacantha against paracetamolinduced liver injury in rabbits has been studied. After administration of a toxic dose of paracetamol, the magnitude of liver marker enzymes boosted up and produced tissue necrosis. When the plant chloroform and methanol extracts in 200, 400 and $600 \mathrm{mg} / \mathrm{kg} /$ day doses for a week were administered p.o. to rabbits, less increase in enzymes (ALT, AST \& ALP) and bilirubin level was observed as compared to paracetamol treated group $(\mathrm{p}<0.001)$.
When these alterations in biochemical parameters were compared with the reference (silymarin), a very less difference was observed. The results indicated that extract treated animals showed incredible recovery $(p<0.001)$ and supported by histopathology of liver section. Hepatotoxin treated group showed altered morphology and tissue necrosis while extract treated group showed fewer changes and hepatotoxicity. Phytochemical analysis of $O$. monacantha showed the presence of polyphenols, flavonoids, alkaloids, tannins, saponins and polysaccharides and these were reported to be hepatoprotective (Ali et al., 2013; Mallhi et al., 2014). It may be concluded that hepatoprotective activity of chloroform and methanol extract of $O$. monacantha is due to the presence of these important constituents.

So, it is concluded that $600 \mathrm{mg} / \mathrm{kg}$ of chloroform and methanol extract of $O$. monacantha is highly potent dose as hepatoprotective agent and this potential may be due 
to the presence of the active constituent: polyphenols, flavonoids, alkaloids and tannins.

\section{References}

Ahmad M, Eram S. Hepatoprotective studies on Haloxylon Salicornicum: A plant from cholistan desert. Pakistan J Pharm Sci. 2011; 24: 377-82.

Ahmad SS. Medicinal wild plants from Lahore-Islamabad motorway (M-2). Pakistan J Botany. 2007; 39: 355-75.

Ahsan R, Islam MK, Musaddik A, Haque E. Hepatoprotective activity of methanol extract of some medicinal plants against carbon tetrachloride induced hepatotoxicity in Albino rats. Global J Pharmacol. 2009; 3: 116-22.

Akhtar MS, Asjad HMM, Bashir S, Malik A, Khalid R, Gulzar F, Irshad N. Evaluation of antioxidant and hepatoprotective effects of Khamira Gaozaban Ambri Jadwar Ood Saleeb Wala (KGA). Bangladesh J Pharmacol. 2013; 8: 44-48.

Ali M, Qadir MI, Saleem M, Janbaz KH, Gul H, Hussain L, Ahmed B. Hepatoprotective potential of Convolvulus arvensis against paracetamol-induced hepatotoxicity. Bangladesh J Pharmacol. 2013; 8: 300-04.

Ali M, Ramachandram R, Rafiullah MR, Singh O, Siddiqui AW, Mir SR. Prevention of carbon tetrachloride-induced hepatotoxicity by the ethanol extract of Capparis mooniifruits in rats. Pharma Bio. 2004; 42: 286-88.

Bag AK, Mumtaz SMF. Hepatoprotective and nephroprotective activity of hydroalcoholic extract of Ipomoea staphylina leaves. Bangladesh J Pharmacol. 2013; 8: 263-68.

Balamurugan G, Muthusamy P. Observation of the hepatoprotective and antioxidant activities of Trianthema decandra Linn. (Vallai sharunnai) roots on carbon tetrachloride-treated rats. Bangladesh J Pharmacol. 2008; 3: 83-89.

Bari NM, Zubair M, Rizwan K, Rasool N, Bukhari HI, Akram S, Bokhari HT, Shahid M, Hameed M, Ahmad UV. Biological activities of Opuntia Monacantha Cladodes. International Centre for Chemical and Biological Sciences, University of Karachi. 2012; 34: 990-95.

Galati EM, Tripodo MM, Trovato A, Miceli N, Monforte MT, Biological effect of Opuntia ficus indica (L.) Mill. (Cactaceae). J Ethnopharmacol. 2002; 79: 19-22.

Girish C, Koner BC, Jayanthi S, Rao KR, Rajesh B, Pradhan SC.
Hepatoprotective activity of six polyherbal formulations in paracetamol induced liver toxicity in mice. Indian J Med Res. 2009; 3: 569-78.

Hegde K, Joshi AB. Hepatoprotective and antioxidanteffect of Carissa spinarum root extract against $\mathrm{CCl}_{4}$ and paracetamolinduced hepatic damage in rats. Bangladesh J Pharmacol. 2010; 5: 73-76.

Ibrahim M, Khaja ZU, Narasu ML. Hepatoprotective activity of Boswellia serrata extracts: In vitro and in vivo studies. Int J Pharm Applications. 2011; 2: 89-98.

Kifayatullah M, Waheed I. Evaluation of hydroethanolic extract of Opuntia monacantha haw cladodes for antipyretic activity . World J Pharm Pharmaceut Sci. 2014; 3: 1021-30.

Mallhi TH, Abbas K, Ali M, Qadir MI, Saleem M, Khan YH. Hepatoprotective activity of methanolic extract of Malva parviflora against paracetamol-induced hepatotoxicity in mice. Bangladesh J Pharmacol. 2014; 9: 342-46.

Raja S, Ahamed KF, Kumar V. Antioxidant effect of Cytisus scoparius against carbon tetrachloride treated liver injury in rats. J Ethnopharmacol. 2006; 109: 41-47.

Saboo SS, Tapadiya G, Farooqui IA, Khadabadi SS. Free radical scavenging, in vivo antioxidant and hepatoprotective activity of folk medicine Trichodesma sedgwickianum. Bangladesh J Pharmacol. 2013; 8: 58-64.

Saleem M, Ahmed B, Karim M, Ahmed S, Ahmad M, Qadir MI, Syed NIH. Hepatoprotective effect of aqeous methanolic extract of Rumex dentatus in paracetamol induced hepatotoxicity in mice. Bangladesh J Pharmacol. 2014; 9: 284 -89 .

Saleem M, Ahmed B, Qadir MI, Karim M, Rafiq M, Ahmad M, Ahmad B. Hepatoprotective effect of Chenopodium murale in mice. Bangladesh J Pharmacol. 2014; 9: 124-28.

Saleem M, Naseer F. Medicinal plants in the protection and treatment of liver diseases. Bangladesh J Pharmacol. 2014; 10: 511-26.

Thakare SP, Jain HN, Patil SD, Upadhyay UM. Hepatoprotective effect of Cocculus hirsutus on bile duct ligationinduced liver fibrosis in albino Wistar rats. Bangladesh J Pharmacol. 2009; 4: 126-30.

Yasmin S, Kashmiri AM, Anwar K. Screening of aerial parts of Abutilon bidentatum for hepatoprotective activity in rabbits. J Medicinal Plants Res. 2011; 5: 349-53. 